\title{
Hypoxic preconditioning effect on stromal cells derived factor-1 and C-X-C chemokine receptor type 4 expression in Wistar rat's (Rattus norvegicus) bone marrow mesenchymal stem cells (in vitro study)
}

\author{
Sri Wigati Mardi Mulyani ${ }^{1}$, Diah Savitri Ernawati ${ }^{2}$, Eha Renwi Astuti ${ }^{1}$ and Fedik Abdul Rantam ${ }^{3,4}$
}

1. Department of Dentomaxillofacial Radiology, Faculty of Dental Medicine, Universitas Airlangga, Surabaya, Indonesia;

2. Department of Oral Medicine, Faculty of Dental Medicine, Universitas Airlangga, Surabaya, Indonesia; 3. Stem Cell

Research Center and Development, Airlangga University Surabaya, Indonesia; 4. Lab of Virology and Immunology, Department of Microbiology, Faculty of Veterinary Medicine, Universitas Airlangga, Surabaya, Indonesia. Corresponding author: Diah Savitri Ernawati, e-mail: diah-s-e@fkg.unair.ac.id

Co-authors: SWMM: sri-w-m-m@fkg.unair.ac.id, ERA: eha-r-a@fkg.unair.ac.id, FAR: fedik-a-r@fkh.unair.ac.id Received: 25-01-2018, Accepted: 04-06-2018, Published online: 19-07-2018

doi: 10.14202/vetworld.2018.965-970 How to cite this article: Mulyani SWM, Ernawati DS, Astuti ER, Rantam FA (2018) Hypoxic preconditioning effect on stromal cells derived factor-1 and C-X-C chemokine receptor type 4 expression in Wistar rat's (Rattus norvegicus) bone marrow mesenchymal stem cells (in vitro study), Veterinary World, 11(7): 965-970.

\begin{abstract}
Aim: To examine the effect of hypoxic preconditions on the ability of bone marrow stem cells culture mediated expression C-X-C chemokine receptor type 4 (CXCR4) and stromal cells derived factor-1 (SDF-1) in vitro.

Materials and Methods: Bone marrow mesenchymal stem cells (BMSCs) were derived from 12 femurs of $200 \mathrm{~g}$ Wistar male rats. The animals were euthanized before BMSCs isolation. BMSCs were divided into two groups, control group: Normoxic condition $21 \% \mathrm{O}_{2}$ and treatment group: Hypoxic condition $1 \% \mathrm{O}_{2}$. The characterization of BMSCs was analyzed using flow cytometry by cluster differentiation 34 and cluster differentiation 105 . The expression of CXCR4 and SDF-1 measured using immunocytochemistry immunofluorescence label after 48-h incubation in a low-tension oxygen chamber with an internal atmosphere consisting of $95 \% \mathrm{~N}_{2}, 5 \% \mathrm{CO}_{2}$, and $1 \% \mathrm{O}_{2}$. All data were subjected to a normality test and then analyzed using t-test statistic $(\mathrm{p}<0.05)$.
\end{abstract}

Results: The characterization of bone marrow stem cells showed positive cluster differentiation 34 and cluster differentiation 105. A hypoxic precondition $\left(1 \% \mathrm{O}_{2}\right)$ in culture increases CXCR4 $(\mathrm{p}=0.000)$ and SDF-1 expression than normoxic conditions $(\mathrm{p}=0.000)(\mathrm{p}<0.05)$.

Conclusion: Hypoxic preconditioning with $1 \% \mathrm{O}_{2}$ increase CXCR4 and SDF1 expression.

Keywords: bone marrow stem cells, C-X-C chemokine receptor type 4, hypoxic preconditioning, mesenchymal stem cells, stromal cells derived factor-1.

\section{Introduction}

Mesenchymal stem cells (MSCs) constitute a population of adult stem cells that can transdifferentiate not only into types of mesodermal lineage cells but also into multilineage cell types [1]. Preliminary studies have shown that MSCs are capable of producing a range of cytokines and growth factors such as basic fibroblast growth factor and vascular endothelial growth factor (VEGF). In addition, there is another factor that significantly influences the success of therapy by inducing stem cells to migrate into defective areas. The other factors that can mediate such migration are stromal derived-cell factor 1 (SDF1) and $\mathrm{C}-\mathrm{X}-\mathrm{C}$ chemokine receptor type 4 (CXCR4) [2].

SDF-1 is a small molecule of chemokines which, by binding with a CXCR4 receptor, executes an

Copyright: Mulyani, et al. Open Access. This article is distributed under the terms of the Creative Commons Attribution 4.0 International License (http://creativecommons.org/licenses/ by/4.0/), which permits unrestricted use, distribution, and reproduction in any medium, provided you give appropriate credit to the original author(s) and the source, provide a link to the Creative Commons license, and indicate if changes were made. The Creative Commons Public Domain Dedication waiver (http:// creativecommons.org/publicdomain/zero/1.0/) applies to the data made available in this article, unless otherwise stated. important role in regulating the adhesion, expansion, migration, and homing of MSCs. A recent study indicates that CXCR4 and SDF-1 are highly expressed in bone marrow MSCs (BMSCs), but is lost on culturing at a high passage number. Under hypoxic conditions, a number of cytokines, chemokines including CXCR4 and SDF-1 expression can be re-established, thereby maintaining the efficacy of MSCs. The survival and proliferation of transplanted progenitor cells in tissue would require cell adaptation to the harsh, low oxygen tension environment [3]. The previous study demonstrated that hypoxia preconditioning can increase the ability of transplanted stem/progenitor cells to survive and proliferate ability in vitro [4]. Hypoxia preconditioning mimics the situation that the cells will meet when they are transplanted into the tissue defect. Accordance to the previous study demonstrated thatHypoxia-inducible factor-1 alpha (HIF-1 $\alpha$ ), CXCR4, anti-apoptotic gene Bcl-2, p-Akt, SDF- $1 \alpha$, and VEGF expression were all elevated after hypoxia preconditioning and were further verified by increased anti-apoptosis and migration capacity in vitro and decreased apoptosis and better cardiac rescue potency in vitro. However, the mechanisms 
underlying the beneficial effects of hypoxia preconditioned progenitor cells remain incomplete [5].

The aim of this study was to examine the effect of hypoxic preconditions on MSCs culture to expression CXCR4 and SDF-1 in vitro.

\section{Materials and Methods}

Ethical approval

All animal studies were performed through a protocol approved by the Institutional Animal Care and Use Committee of Faculty of Veterinary Medicine, Universitas Airlangga and complied with the National Research Council's guidelines ethical approval number: No 366-KE through the ethical seminar. The research was conducted at an experimental laboratory within the Stem Cell and Tissue Engineering Development Centre, Universitas Airlangga, Surabaya, Indonesia.

\section{Animal model}

All animals were housed in polycarbonate cages, subjected to a 12-h light-dark cycle at the constant temperature of $23^{\circ} \mathrm{C}$, and fed a standard pellet diet (expanded pellets, Stepfield, Witham, Essex, UK) with tap water ad libitum. The exploration of MSCs involved the use of 200 femurs from 12 Wistar male rats. The sampling technique of the BMSCs from the rat's femurs was determined by Lemeshow's method. The animals were euthanized before Bone Marrow isolation.

\section{BMSCs isolation}

BMSCs isolation and culture according to Rantam et al.'s [6] method aspirate from femur bones produces sufficient marrow to be cultured. Aspirate of bone marrow was attached to a $15 \mathrm{ml}$ Heparin tube (Sigma-Aldrich $^{\circledR}$, USA) previously filled with $3 \mathrm{ml}$ $\alpha$-minimum essential medium (MEM). Each aspirate was transferred to a $15 \mathrm{ml}$ sterile tube with a blue cap and diluted with $1 \times$ phosphate buffer saline (PBS) (Sigma-Aldrich $^{\circledR}$, USA) sterile to a total volume of $8 \mathrm{ml}$. Each tube was then rinsed twice with $5 \mathrm{ml} \times$ PBS, and the contents were combined with an aspirate solution. In every case, the aspirate was placed in a Ficoll (Sigma-Aldrich ${ }^{\circledR}$, USA) temperature chamber in a separate $15 \mathrm{ml}$ tube. Furthermore, each aspirate was coated with Ficoll before being centrifuged (Sorvall ${ }^{\mathrm{TM}}$ MX Series Floor Model Micro-Ultracentrifuge, Thermo Fisher, USA) at $1600 \mathrm{rpm}$ for $15 \mathrm{~min}$ at room temperature. After centrifugation, the collection was effected at the "buffy coat" location on the surface of Ficoll-PBS using a sterile Pasteur pipette and placed in a $15 \mathrm{ml}$ tube (Sigma-Aldrich ${ }^{\circledR}$, USA).

Each sample was diluted with $1 \times$ PBS to a total volume of $15 \mathrm{ml}$, with the tube being turned 3-5 times as a means of achieving an even mix. At the next stage, centrifugation was undertaken for $10 \mathrm{~min}$ at a speed of $1600 \mathrm{rpm}$ before the supernatant and cells suspended in $6 \mathrm{ml}$ of cell culture medium (CCM) were removed before heating. Having placed between $5 \mathrm{~cm}^{2}$ and
$10 \mathrm{~cm}^{2}$ of cells on the plate, they were incubated at $37^{\circ} \mathrm{C}$ at $5 \% \mathrm{CO}_{2}$ moisture and allowed to attach to the cell for 18-24 h. Approximately $24 \mathrm{~h}$ later, the media and cells not attached were disposed of. $5 \mathrm{ml} 1 \times \mathrm{PBS}$ was then added before being heated in the culture, shaken well and used to cover the surface area. It was then disposed of with $1 \times$ PBS before the washing process being repeated twice.

Ten minutes later, $10 \mathrm{ml}$ of fresh CCM was added to the dish before it was returned to the incubator. The cells were incubated at $37^{\circ} \mathrm{C}$ and $5-10 \% \mathrm{CO}_{2}$ moisture with the culture being observed daily using an inverted microscope. Every 3 days, the media were removed and the cells rinsed with $5 \mathrm{ml}$ or $10 \mathrm{ml}$ of $1 \times$ PBS before heating. The PBS was subsequently discarded and the dish filled with $10 \mathrm{ml}$ of fresh CCM. This process was continued until the concentration of confluent cells reached between $60 \%$ and $80 \%$. If the cell developed in the cell plant, the latter had to be balanced in the incubator at $5 \% \mathrm{CO}_{2}$ moisture and $37^{\circ} \mathrm{C}$ for $48 \mathrm{~h}$ before use.

\section{BMSCs identification surface markers by flow cytometry}

BMCs were harvested by centrifugation at the end of coculture and made in single cells before flow cytometry analysis. The cells are then incubated in test tubes or microtiter plates with unlabeled or fluorescently conjugated antibodies and analyzed through flow cytometry (Becton Dickson FACSVerse, San Diego, USA). MSCs were trypsinized for identification of a number of MSC surface markers, approximately $2 \times 10^{5}$ cells per sample were washed twice with PBS. The antibodies for surface markers were anti-CD34 - Allophycocyanin (Cat no. I345804) anti-CD105 Fluorescein Isothiocyanate (FITC) (Cat. No 561443) (Becton Dickson Pharmingen, San Diego, USA).

\section{BMSCs culture}

Bone marrow samples were dissolved in three equal volumes of the MSC growing medium and distributed uniformly across $10 \mathrm{~cm}$ culture dishes. Each dish produced $10 \mathrm{ml}$ of diluted aspirate. Stored in an incubator (Thermo Scientific Heraeus, USA) with 5\% $\mathrm{CO}_{2}$ and cultured at a constant temperature of $37^{\circ} \mathrm{C}$ for 4-5 days. The medium was replaced every 3-4 days, and the contamination of red cells and unreplicated, unattached cells were eventually diluted and rinsed to eradicate it.

Small MSC colonies of fibroblast cells were attached and perceptible within 5-7 days. After 12-14 days, small colonies could easily be detected. In this condition, cells were rinsed with serumfree $\alpha$-MEM and subculture. $5 \mathrm{ml}$ of $0.05 \%$ trypsin was added and, after a few minutes, cells began to be dispatched from the substrate. Dial the observations under a microscope (JEOL, JSMT1000, Scanning Microscope, Japan). The trypsin/ethylenediaminetetraacetic acid (Sigma-Aldrich ${ }^{\circledR}$ USA) 
solution could be carefully aspirated and removed as long as the full cells had not been delivered. If the removal of cells from the substrate had begun, a fresh growing medium containing fetal bovine serum was added which eliminated trypsin activity. The MSCs were then flushed from the surface with a flask grower incorporating a pipette and divided into two dishes at this stage of low concentration and then rapidly expanded. Each dish was filled with $10 \mathrm{ml}$ of cell susceptibility before being placed in 5\% $\mathrm{CO} 2$ incubator. BMSCs were divided into two groups, control group: Normoxic condition $21 \% \mathrm{O}_{2}$ and treatment group: hypoxic condition $1 \% \mathrm{O}_{2}$.

\section{Hypoxia preconditioning}

Hypoxia was achieved by placing the cells in a Modular Incubator Chamber (Billups-Rothenberg; Del Mar, CA) according to the manufacturer's instructions. After a brief time spent in the chamber, the cells were flushed with a mixture of $0.1 \% \mathrm{O}_{2}, 5 \% \mathrm{CO}_{2}$, and $94.9 \% \mathrm{~N}_{2}$ for $5 \mathrm{~min}$. The chamber was then closed and the cells incubated at $37^{\circ} \mathrm{C}$ for various lengths of time. Next, the cells were cultured under normoxic or hypoxic conditions for $3 \mathrm{~h}, 6 \mathrm{~h}, 12 \mathrm{~h}$, and $24 \mathrm{~h}$.

\section{Identification of CXCR4 and SDF-1 expression by immunofluorescence}

Trypsin was added and centrifuged at $1600 \mathrm{rpm}$ for $5 \mathrm{~min}$. The pellets were added to $1 \mathrm{ml}$ of $\alpha$-MEM growth medium (Sigma-Aldrich ${ }^{\circledR}$, USA), suspended and grown on a special glass of $20 \mu \mathrm{l}$. The object glass was placed in a box containing wet paper and then incubated at $37^{\circ} \mathrm{C}$ for $1 \mathrm{~h}$ before being washed 4 times with PBS and dried. Anti-CXCR4 (Cat No. MAB172) and anti-SDF-1 (Cat No. MAB350) monoclonal antibodies (Sigma Aldrich ${ }^{\circledR}$, USA) were added to each sample and then incubated at $37^{\circ} \mathrm{C}$ for $45 \mathrm{~min}$. After that, the PBS washing and drying processes were repeated. At the next immunofluorescence, FITC labeled examination on glass object with $50 \%$ glycerin dropped above the glass object and viewed the results with a fluorescent microscope (Automated Fluorescence Microscope, BX63, Olympus ${ }^{\circledR}$, USA).

\section{Statistical analysis}

Data in normal distribution were analyzed using a t-test. Statistical analysis was analyzed using of Statistical Package for the Social Sciences (SPSS) 17.0 software for windows 8.1 by SPSS Inc., Chicago, United States.

\section{Results}

Flow cytometry analysis of BMSC phenotypes and BMSC cultures treated with hypoxic preconditioning was expressed more strongly at CD105 (70.07\%) than the normoxic condition (26.12\%) and CD34 expression negatively in both conditions (Figure-1). The mean of SDF-1 and CXCR4 expression significantly expressed in hypoxic preconditioning group than normoxic. The t-test result indicated a significant difference $(\mathrm{p}<0.05)$ between the SDF1/C-X-C motif chemokine 12 (CXCL12) expression between groups (Figure-2 and Table-1). The t-test result demonstrated that there was a significant difference $(p<0.05)$ between CXCR4 expressions of the hypoxic preconditioning group and the normoxic group (Figure-3 and Table-2).

The immunofluorescence of SDF-1 expression result showed the normoxic condition $\left(\mathrm{O}_{2} 21 \%\right)$ to be weakly expressed but more strongly so after a 48 -h hypoxic precondition $\left(\mathrm{O}_{2} 1 \%\right)$ (Figures-4 and 5). The immunocytochemical of CXCR4 expression result showed weakly expressed in normoxic condition $\left(\mathrm{O}_{2} 21 \%\right)$ but strongly expressed (chocolate chromogen) in hypoxic condition $\left(\mathrm{O}_{2} 1 \%\right)$ (Figure-6).

\section{Discussion}

The important factor in cell-based regenerative therapy is the ability of stem cells to migrate to the defect areas through trafficking and successful engraftment when stem cells are transplanted. This is strongly influenced by the CXCR4 chemokine receptor bond with the SDF-1 ligand chemokine. The loss of this chemokine receptor during expansion in vitro culture will decrease the regenerative ability of stem cells [7]. The culture environment affects cell aging and expression of the chemokine marker that plays

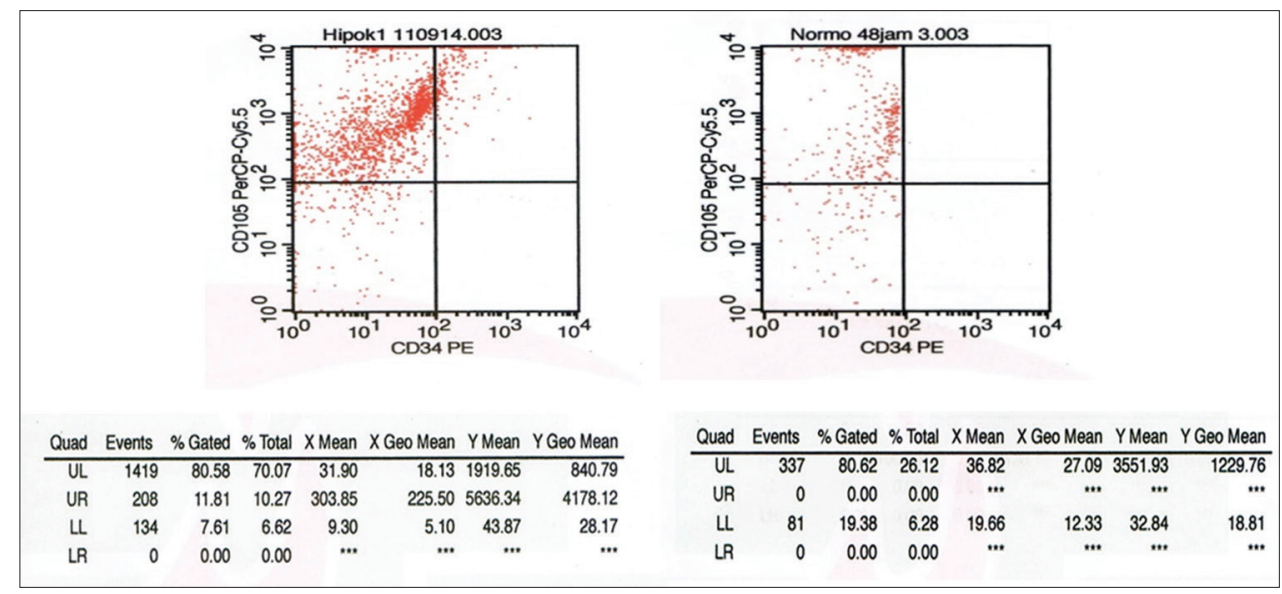

Figure-1: Phenotypic characterization of bone marrow mesenchymal stem cells identified by flow cytometry examination. 


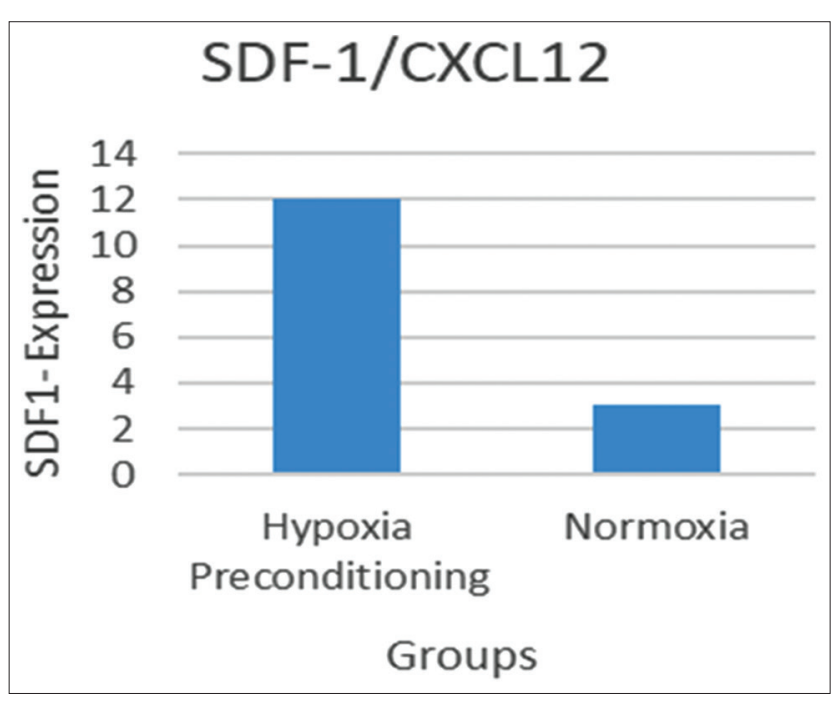

Figure-2: The mean of stromal cells derived factor-1/C$\mathrm{X}-\mathrm{C}$ motif chemokine 12 expressions in bone marrow mesenchymal stem cells cultured in both hypoxia preconditioning and normoxia group.

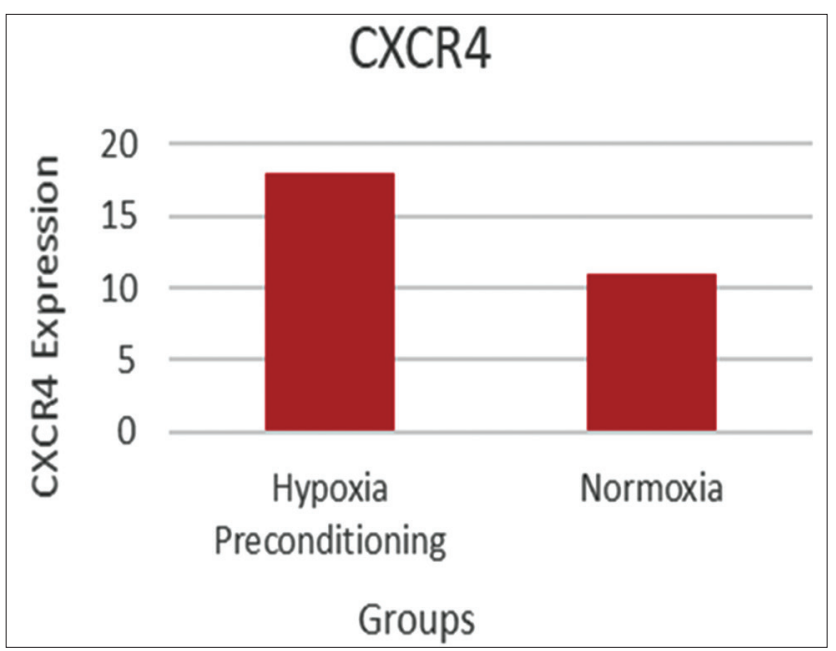

Figure-3: The mean of $\mathrm{C}-\mathrm{X}-\mathrm{C}$ chemokine receptor type 4 expression in mesenchymal stem cells cultured in both hypoxia preconditioning and normoxia group with ICC examination.
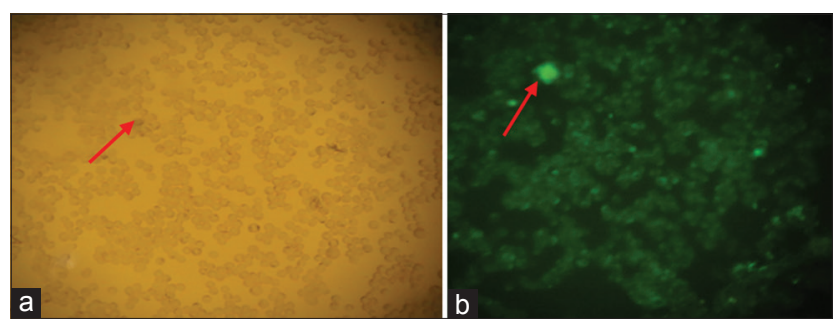

Figure-4: The expression of stromal cells derived factor-1 at $4^{\text {th }}$ passage in a normoxic group with $100 \times$ magnification. (a) Mesenchymal stem cells without filter; (b) with fluorescent filter (NikkonH600L Microscope; digital camera DS Fi2 300 megapixel).

an important role in migratory cells and engraftment when MSCs are transplanted. These problems can be minimized by modifying the microenvironment in stem cell culture by providing precondition of hypoxia with the oxygen concentration in accordance with its niche environment $\left(\mathrm{O}_{2} 1-3 \%\right)$ [8].

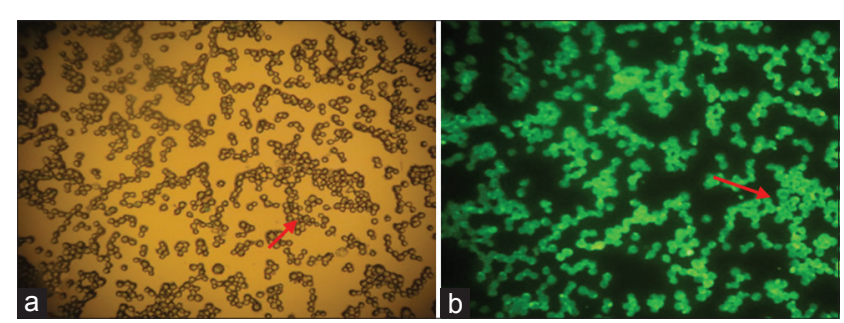

Figure-5: The expression of stromal cells derived factor-1 at $4^{\text {th }}$ passage in hypoxic preconditioning group with $100 \times$. (a): Mesenchymal stem cells without filter; (b) with fluorescence filter (NikkonH600L Microscope; digital camera DS Fi2 300 megapixel).

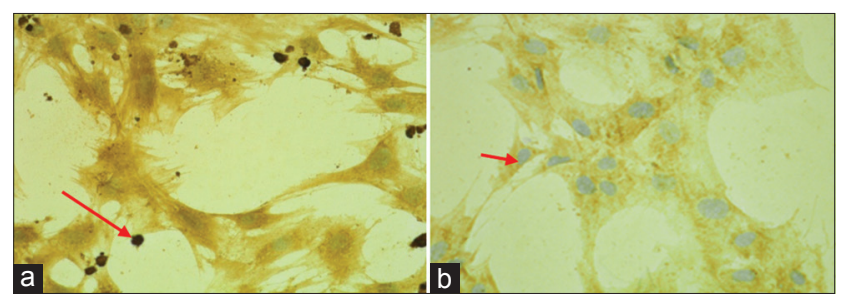

Figure-6: C-X-C chemokine receptor type 4 expression (chocolate chromogen) on the mesenchymal stem cell hypoxic preconditioning group (a) showed strong expression, whereas the normoxic group demonstrated weak expression (Slide B) with immunocytochemistry with $400 \times$ (NikkonH600L Microscope; digital camera DS Fi2 300 megapixel).

Table-1: T-test result of SDF-1 expression in BMSCs culture hypoxic preconditioning and normoxic groups.

\begin{tabular}{lcc}
\hline Group & SDF-1 & Significant \\
\cline { 2 - 2 } & Mean \pm SD & \\
\hline Hypoxic & $11.677 \pm 2.447$ & $\mathrm{p}=0.000^{*}$ \\
Normoxic & $3.517 \pm 0.969$ & \\
\hline
\end{tabular}

*Significant $(p<0.05)$. SDF-1=Stromal cells derived factor-1, BMSCs=Bone marrow mesenchymal stem cells, $\mathrm{SD}=$ Standard deviation

Table-2: T-test result of CXCR4 expression in BMSCs culture hypoxic preconditioning and normoxic groups.

\begin{tabular}{lcc}
\hline Group & Mean \pm SD & P \\
\hline Hypoxic & $18.200 \pm 5.596$ & $0.000^{*}$ \\
Normoxic & $10.750 \pm 5.748$ & \\
\hline
\end{tabular}

*Significant $(p<0.05)$. BMSCs=Bone marrow mesenchymal stem cells, $\mathrm{SD}=$ Standard deviation, $\mathrm{CXCR} 4=\mathrm{C}-\mathrm{X}-\mathrm{C}$ chemokine receptor type 4

MSCs are known to have some beneficial properties such as being found in BMSCs [9]. Previous studies reported the ability of MSCs to secrete cytokines, chemokine, and growth factors in cultured cells which play an important role in the regeneration process such as SDF-1, CXCR4, VEGF, fibroblast growth factor, and insulin-like growth factor. These factors contribute to the migration cell process, survival cells, angiogenesis, cell proliferation, and differentiation that relates to tissue repair and regeneration [10].

The decreased potential of MSCs in vitro may be due to cell culture conditions and the total subcultures performed. Sohni and Verfaillie [11] revealed that the 
higher the number of passages made in a stem cell culture will decrease the potential for differentiation, viability, and effectiveness. Previous studies reported that term culture (40 days) will lead to loss of chemokine receptor expression followed by decreased expression of specific surface receptors (CD105 and CD90). Therefore, it can be concluded that MSCs require microenvironment to maintain their viability and plasticity [12]). Several studies suggest that hypoxic preconditioning will activate some transcription factors in the nucleus such as HIF-1 $\alpha$, nuclear factor kappa $\beta$, Wnt4, and miR210, where these will also interact with paracrine factors such as MEK, PI3K, Erk, and Akt that will increase the secretion of SDF-1 and CXCR4 expression [13].

One of the primary functions of the SDF1CXCR4 is the trafficking regulation of MSC cells in homing in on the injury site [14]. The previous study demonstrated that MSC therapy to mice that produced a defect in their brains suggested that the migration process from MSCs to defective areas is probably mediated by chemokine and their receptors SDF1CXCR4 through the mechanism of MSCs trafficking G-protein-coupled receptor signaling. SDF1-CXCR4 also plays a role in cellular retardation, proliferation, and differentiation mechanisms by MAPK/PI3K signaling pathway through increased expression of BCL2 and ERK [15].

In this study was to determine whether hypoxia preconditioning can improve the expression of chemokine receptors and ligand (CXCR4-SDF-1) in cells culture. BMSCs were taken from the femur of male Wistar rat and are cultured in hypoxic conditions $\left(\mathrm{O}_{2} 1 \%\right)$ at the $4^{\text {th }}$ passage and compared with normoxic condition $\left(\mathrm{O}_{2} 21 \%\right)$. The phenotypic characterization of MSCs using by flow cytometry in hypoxic condition showed strong expression of $\mathrm{CD}$ 105 compared to normoxic condition, the specific surface marker of MSCs and negative expression of CD 34 in both conditions, the specific marker of hematopoietic stem cells. It was assumed that the cell culture in hypoxic condition has purely isolated of MSCs than normoxic condition cell culture (Figure-1). The result of an examination on the effect of hypoxic precondition in the cell culture using immunofluorescence and immunocytochemical indicated strongly expressed of SDF-1 and CXCR4 after $48 \mathrm{~h}$ hypoxic precondition compared to the normoxic condition.

It was in accordance with Yellowley that revealed under hypoxic condition a number of cytokines, chemokines including CXCR4 and SDF-1 expression can be reestablished, so the efficacy of MSCs can be maintained. The expression of the transcription factor hypoxia-inducible factor-1, a-subunit (HIF-1a), may drive the upregulation of SDF-1/ CXCL12 in hypoxic condition and ultimately regulate the homing of CXCR4 stem cells and progenitor cells. Under hypoxic conditions, the activity of PHD2 is reduced, and HIF-1a degradation is inhibited; HIF-1a accumulates and binds to its consensus sequence, the hypoxia-responsive element on HIF-1a target genes. 63 HIF-1a has been shown to induce the expression of SDF-1 and CXCR4. Finally, when MSCs transplanted can improve the ability of MSCs to migrate into defected tissues, proliferate, and differentiate into origin-like cells, and promote resident stem cells growth and proliferation.

\section{Conclusion}

Hypoxic preconditioning $1 \% \mathrm{O}_{2}$ can promote increasing CXCR4 and SDF1 expression that may play an important role to improve BMSCs migration into defect areas, proliferation, and differentiation into origin-like cells.

\section{Author's Contributions}

SWMM, DSE, ERA, FAR: Conception and design of the study. SWMM, DSE, ERA, FAR: Acquisition of data. SWMM, DSE, ERA, FAR: Analysis and interpretation of the data. SWMM, DSE, ERA, FAR: Drafting and revising the manuscript critically for important intellectual content. SWMM, DSE, ERA, FAR: All authors have read and approved the final manuscript.

\section{Acknowledgments}

The authors would like to thank the Faculty of Dental Medicine, Universitas Airlangga, Surabaya, Indonesia. This laboratory work was supported by grants from DIPA BO. The authors would like to thank Universitas Airlangga and Stem Cell and Tissue Bank Center RSUD Dr. Soetomo Surabaya, Indonesia. The research grant is funded by Penelitian Unggulan Perguruan Tinggi (PUPT) 2017 DIPA DRPM Research, Technology and Higher Education Ministry of Indonesia. Letter of Appointment Agreement of Research Program number: 137, PUPT, thp-I/2017; 586, UN3/2017 May 12, 2017.

\section{Competing Interests}

The authors declare that they have no competing interests.

\section{References}

1. Pratheesh, M. D., Dubey, P. K., Nath, A., Gade, N. E., Kumar, R., and Sharma, G. T. (2011) Mesenchymal stem cells and it's Characterization. Vet. World, 4(12), 571.

2. Safitri, E., Utama, S., Bumi, C., Mulyani, S.W.M., Retnowati, E., Prasetyo R.H., Mas'ud, H., Aulani'am, A, Ferdiansyah, M. and Fedik, A.R. (2014) Hypoxic preconditioning for viable and self renewing mesenchymal stem cells (Mscs) as the regeneration of spermatogenesis process. Adv. Nat. Appl. Sci., 8: 42-47.

3. Khan, M., Kwiatkowski, P., Rivera, B.K. and Kuppusamy, P. (2010) Oxygen and oxygenation in stem-cell therapy for myocardial infarction. Life Sci., 87: 269-274.

4. Chacko, S.M., Ahmed, S., Selvendiran, K., Kuppusamy, M.L., Khan, M. and Kuppusamy, P. (2010) Hypoxic preconditioning induces the expression of prosurvival and proangiogenic markers in mesenchymal stem cells. Am. J. Physiol. Cell Physiol., 299: C1562-C1570. 
5. Yan, F., Yao, Y., Chen, L., Li, Y., Sheng, Z. and Ma, G. (2012) Hypoxic preconditioning improves survival of cardiac progenitor cells: Role of stromal cell-derived factor- $1 \alpha-$ CXCR4 axis. PLoS One, 7: e37948.

6. Rantam, F., Ferdiansyah, M.N. and Purwati, A. (2009) Stem cell exploration. Methods of isolation and culture. Airlangga University Press, Surabaya. p10-25.

7. Tran, S.D., Pillemer, S.R., Dutra, A., Barrett, A.J., Brownstein, M.J., Key, S., Pak, E., Leakan, R.A., Kingman, A., Yamada, K.M., Baum, B.J. and Mezey, E. (2003) Differentiation of human bone marrow-derived cells into buccal epithelial cells in vivo: A molecular analytical study. Lancet, 361: 1084-1108.

8. Haque, N., Rahman, M.T., Kasim, N.H.A. and Alabsi, A.M. (2013) Hypoxic culture conditions as a solution for mesenchymal stem cell based regenerative therapy. Sci. World J., 632972; 1-2.

9. Coutu, D.L. and Galipeau, J. (2011) Roles of FGF signaling in stem cell self-renewal, senescence and aging. Aging (Albany NY), 3: 920.

10. Chow, D.C., Wenning, L.A., Miller, W.M. and Papoutsakis, ET.
(2001) Modeling O2 distributions in the bone marrow hematopoietic compartment. I. Krogh's model. Biophys. J., 81: 675-684.

11. Sohni, A. and Verfaillie, C.M. (2013) Mesenchymal stem cells migration homing and tracking. Stem Cells Int., 130763: 1-9.

12. Kermer, P., Liman, J., Weishaupt, J.H. and Bähr, M. (2004) Neuronal apoptosis in neurodegenerative diseases: From basic research to clinical application. Neurodegener. Dis., 1: 9-19.

13. Lin, C.Y., Chang, F.H., Chen, C.Y., Huang, C.Y., Hu, F.C., Huang, W.K., Ju, S.S. and Chen, M.H. (2011) Cell therapy for salivary gland regeneration. J. Dent. Res., 90: 341-346.

14. Cencioni, C., Capogrossi, M.C. and Napolitano, M. (2012) The SDF-1/CXCR4 axis in stem cell preconditioning. Cardiovasc. Res., 94: 400-407.

15. Feng, J., van der Zwaag, M., Stokman, M.A., van Os, R. and Coppes, R.P. (2009) Isolation and characterization of human salivary gland cells for stem cell transplantation to reduce radiation-induced hyposalivation. Radiother. Oncol., 92: 466-471.

$* * * * * * * *$ 